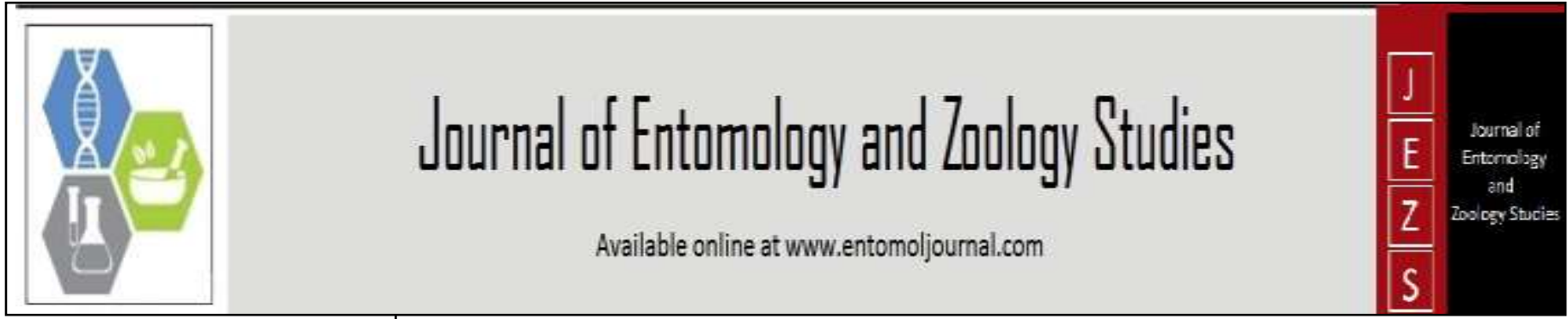

E-ISSN: 2320-7078

P-ISSN: 2349-6800

www.entomoljournal.com

JEZS 2021; 9(2): 578-586

(C) 2021 JEZS

Received: 18-12-2020

Accepted: 05-02-2021

Waykar Bhalchandra Professor, Department of Zoology, Dr. Babasaheb Ambedkar Marathwada University, Aurangabad, Maharashtra, India

Mahesh A Joshi

Department of Zoology, Dr.

Babasaheb Ambedkar

Marathwada University,

Aurangabad, Maharashtra, India

Corresponding Author:

Waykar Bhalchandra

Professor, Department of

Zoology, Dr. Babasaheb

Ambedkar Marathwada

University, Aurangabad,

Maharashtra, India

\section{Physicochemical properties of blended raw honey samples collected from three different locations of Kannad taluka of Aurangabad district (MS), India}

\author{
Waykar Bhalchandra and Mahesh A Joshi
}

DOI: https://doi.org/10.22271/j.ento.2021.v9.i2i.8534

\section{Abstract}

The present study was carried out to investigate the physicochemical properties of blended raw honey samples collected from three different locations from Kannad taluka of Aurangabad district (MS). The parameters like moisture content, $\mathrm{pH}$, electrical conductivity, total reducing sugars, glucose, fructose, fructose glucose ratio, sucrose, Hydroxymethylfurfural (HMF), proline, protein content, Vitamin C, lipid content, were analyzed by AOAC method (2000). The results clearly indicate that the samples compared favorably with samples in many parts of the world and also fall within the limits of international standards. The variations in the physicochemical properties of honey samples are related to differences in the floral sources, climatic conditions and site of collection to the studied area. Overall the results indicate that the nutritional quality of honey was different from species to species and from location to location.

Keywords: Raw honey, Hydroxymethylfurfural, physicochemical properties, floral sources, etc.

\section{Introduction}

Honey, one of the major bee products, is a sweet viscous natural fluid made from the nectar of plants. Honey was defined as "the sweet substances produced by honeybees from the nectar of blossoms or from secretions on living plants, which the bees collect, transform and store in honey combs" ${ }^{[1]}$. It is a concentrated aqueous solution of invert sugar that comprises a mixture of other compounds like carbohydrates, amino and organic acids, minerals, aromatic substances, pigments, waxes and pollen grains to make it complex ${ }^{[2,3,4]}$. Many scientists reported that natural honey contains about 200 substances, which consist of not only a highly concentrated solution of sugars, but also the complex mixture of other saccharides, amino acids, peptides, enzymes, proteins, polyphenols, organic acids, carotenoid like substances, vitamins and minerals ${ }^{[5,6,7]}$.

The composition of honey varies due to the influence of plants, climate, and environmental conditions as well as the ability of the beekeeper. The alteration of the physicochemical properties of honey depends on the nectar and pollen of the original plant, color, moisture, and protein and minerals contents. Therefore, honey is related to its botanical origin, processing and storage, and climatic factors that occur during the flow of nectar, and to the temperature at which the honey matures in the hive ${ }^{[8]}$. Although, the main components of honey are almost identical in all honey, yet the chemical composition and physical properties of natural honey depend on the floral sources, the processing, storage and climatic conditions ${ }^{[9,10,11]}$.

Honey has become one of the most commercial agricultural products in many countries in the world. Honey is the major bee product which has important nutritional value and provides significant economic contributions. Quality control of honey is important to determine its suitability for processing and to boost the demand of the market. Honey shall not have foreign taste, going to ferment, heated to the amount or degree of destroying its natural enzymes and a substance that endanger human health ${ }^{[12]}$. The international honey commission (IHC) has proposed certain constituents as quality criteria for honey. These include moisture content, electrical conductivity, reducing sugars, amount of fructose and glucose, sucrose content, individual sugars, mineral, free acidity, diastase activity, HMF content, invertase activity, proline content and specific rotation ${ }^{[13,14]}$. 
The physicochemical properties of honey are helpful for the comparison of natural honey samples from different locations and also serve as important indicators that can help to distinguish between natural and artificial honey. The physicochemical properties provide the parameters for the characterization and classification of honey. They also serve as criteria used for choosing appropriate processing and packaging techniques and technological applications of natural honey ${ }^{[15]}$. Moreover, the apiculture sector has received little research and developmental attention and the honey produced in the different agro-ecologies of the country has not been characterized to date.

To date no study has been conducted to examine the quality and physicochemical properties of honey produced in Kannad taluka of Aurangabad district. To increase the income of beekeepers and the marketability of honey produced in the study area, it is important to determine the physicochemical properties of the honey face to face national and international standards set for honey. The present study deals with the different physicochemical parameters of honey samples found in three different locations of Kannad taluka of Aurangabad district.

\section{Materials and methods}

A) Collection of samples: Honey samples were collected from three bee species (Apis florea, Apis cerana indica and Apis dorsata) from three different locations of Kannad taluka of Aurangabad district, (M. S.) during October 2015 September 2016. Total of 23 different honey samples were collected as follows: 9 from an agricultural area, 9 from road side area and 5 from the forest area. Area wise honey samples were blended in equal quantities (100 gram each) and honey samples were put in air tight sterilized plastic containers. They were labeled, brought to the laboratory and stored at 0 $4^{\circ} \mathrm{C}$ until analysis.

B) Study area: The total area of Aurangabad district is about 10.07 lakh hector is out of which 8.12 lakh hector is under agriculture and 0.12 lakh is forest area. Geographically, Kannad taluka of Aurangabad district is located at $20^{\circ} 27^{\prime} \mathrm{N}$ $75^{\circ} 13^{\prime}$ E. The average altitude of this area is 633 meters above sea level. Honey samples were collected from three different locations of Kannad taluka of Aurangabad district.

\section{i. Agricultural area}

There are total of 9 samples of honey harvested from the agriculture areas. In which 7 samples of Apis florea, 1 sample of Apis cerana indica and 1 sample of Apis dorsata bee species. The distance between these hives is above 20 meters from the road side. Farmers are engaged in cultivation of traditional crops like sunflowers, mustard, maize, cotton, jowar, pearl millet, pulses, onion, other seasonable vegetables and also cultivating fruit plants like pomegranate, sweet orange etc. in the area provided and independent system in which the bees assist to carry out cross pollination.

This area includes locations viz., Tapargaon, Hatnur, Devgaon (Rangari), Adgaon (Jehur), Pishor, Wasadi and Lohagaon. The distance between the two sampling stations is approximately $1-20 \mathrm{~km}$.

\section{ii. Road side area}

There are total 9 samples of honey harvested from road side area. In which 8 samples of Apis florea and 1 sample of Apis dorsata bee species were obtained. The distance between these hives is between the 20 meters from the road side.

This area includes locations viz., Tapargaon, Hatnur, Kannad City, Shivrai, Panpoi phata, Andhaner road and Hivarkheda. The distance between the two sampling stations is approximately $1-5 \mathrm{~km}$.

\section{iii. Forest area}

The Gautala forest is situated $8 \mathrm{~km}$ away from Kannad Taluka. The forest is famous for woody plants, shrubs, medium size as well as huge trees, lianas and climbers etc. The forest has spread upon Sahyadri hill ranges of Western Ghats. The forest acquired about 260 sq. $\mathrm{km}$ area on the boundary of Marathwada and Khandesh. The forest is confined to the Ajanta Satmala ranges in Kannad and Sillod taluka. Geographically it is situated $74^{\circ}-55^{\circ}$ and $75^{\circ}-15^{\circ}$ east longitude and $20^{\circ}-15^{\circ}$ and $20^{\circ}-30^{\circ}$ north latitude ${ }^{[16]}$. There are total 5 samples of honey harvested from the Gautala forest area. In which 3 samples of Apis florea, 1 sample of Apis cerana indica and 1 sample of Apis dorsata bee species were obtained.

The following wild plants species were found in forest areaAmaranthus tricolor (Tandul-kunjra), Aegle marmelos (Bel), Amaranthus spinosus (Kante bhaji), Bauhinia purpurea (Rakta Kanchan), Carissa carandas (Karvand), Coleus barbatus (Karmelo), Luffa cylindrica (Ghosala), Moringa oleifera (Shevga), Oxalis corniculata (Ambutee), Prosopis cineraria (Shemi), Portulaca oleracea (Ghol), Sesbania grandiflora (Hatga), Tamarindus indica (Chinch), Mangifera indica (Aamba), Limonia acidissima (Kavath), and Phyllanthus emblica (Aavla).

\section{C) Physicochemical Analysis}

Honey samples were analyzed for $\mathrm{pH}$, moisture, electrical conductivity, total reducing sugars, glucose, fructose, F/G ratio, sucrose, Vitamin C, lipid content, Hydroxymethylfurfural (HMF), Proline content and protein content. All of these analyses were done following AOAC Method (2000) ${ }^{[17]}$.

i. Determination of $\mathbf{p H}-\mathrm{The} \mathrm{pH}$ was measured by means of a pH-meter ( $\mathrm{pH}$ ep. pocket sized, HANNA Instruments, Portugal. Range $-1-14$, accuracy $\pm 0.1 \mathrm{pH}$ ). The $\mathrm{pH}$ of a $10 \%(\mathrm{w} / \mathrm{v})$ solution of homogenized honey prepared in boiled warm water was measured by a $\mathrm{pH}$ meter. The $\mathrm{pH}$ meter was calibrated using standard buffers of $\mathrm{pH} 4.0,7.0$ and 9.0 prior to measuring the $\mathrm{pH}$ of the samples.

ii. Determination of Electrical Conductivity- The Electrical Conductivity was determined by a conductivity meter (Model no. HI96301-2, Range 0-19900 $\mu \mathrm{S} / \mathrm{cm}$, Accuracy $\pm 0.2 \%$, HANNA Instruments, Portugal). Electrical Conductivity meter was first calibrated with water and then conductivity meter was dipped into honey Solution (10.0\%) and reading was noted after stabilization of instrument.

iii. Determination of Moisture Content- Moisture content of honey samples were determined by using refractrometer reading at $20^{\circ} \mathrm{C}$ and obtained corresponding percentage moisture from AOAC standard table. Moisture content was determined by using refractometer (Model no. ZL03303431.1, Pal-3, Atago pocket refractometer Japan). The refractometer was calibrated by adjusting zero. After that 2-3 drops of 
honey was put on the prism and reading was noted in the record book for all honey samples.

iv. Determination of Vitamin $\mathbf{C}$ by Colorimetric Method Extraction: Take $1 \mathrm{gm}$ of honey in $10 \mathrm{ml}$ of $4 \%$ oxalic acid solution in conical flask. Add bromine water dropwise with constant (the enolic hydrogen atoms in ascorbic acid are removed by bromine). When the extract turns orange yellow due to excess of bromine, expel it by blowing in air. Make up to a known volume $25 \mathrm{ml}$ with $4 \%$ oxalic acid solution. Similarly, convert $10 \mathrm{ml}$ stock ascorbic acid solution into dehydro form by bromination.

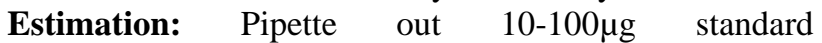
dehydroascorbic acid solution into a series of tubes. Similarly pipette out different aliquots (0.1-2ml) of brominated samples. Make up the volume in each tube to $3 \mathrm{ml}$ by adding distilled water. Add $1 \mathrm{ml}$ of DNPH reagent followed by 1-2 drops of thiurea to each tube. Set a blank as above but with distilled water in place of ascorbic acid solution. Mix the content of the tube thoroughly and incubate at $37^{\circ} \mathrm{C}$ for $3 \mathrm{hrs}$. After incubation dissolved the orange-red osazone crystals formed by adding $7 \mathrm{ml}$ of $80 \%$ sulphuric acid. Absorbance was measured at $540 \mathrm{~nm}$. Plot a graph of ascorbic acid concentration versus absorbance and calculate the ascorbic acid content in the samples.

v. Determination of HMF content: HMF was determined by Spectrophotometric method White, (1979) ${ }^{[18]}$ after clarifying samples with potassium hexacyanoferrate (Carrez I) and zinc sulfate -7- hydrate (Carrez II) and the addition of sodium bisulphate. Absorbance was determined at $284 \mathrm{~nm}$ and $336 \mathrm{~nm}$ in Elico Biospectrophotometer BL 200.

Five grams of honey were dissolved in $25 \mathrm{ml}$ of water, transferred quantitatively into a $50 \mathrm{ml}$ volumetric flask, added by $0.5 \mathrm{ml}$ of Carrez solution I and $0.5 \mathrm{ml}$ of Carrez II and make up to $50 \mathrm{ml}$ with water. The solution was filtered through paper rejecting the first $10 \mathrm{ml}$ of the filtrate. Aliquots of $5 \mathrm{ml}$ were put in two test tubes; to one tube was added $5 \mathrm{ml}$ of distilled water (sample solution); to the second was added $5 \mathrm{ml}$ of sodium bisulphite solution $0.2 \%$ (reference solution). The absorbance of the solutions at 284 and $336 \mathrm{~nm}$ was determined using Elico Boispectrophotometer BL 200.

vi. Determination of Protein content: The protein content of honey was measured according to Lowry et al., (1951) ${ }^{[19]}$. Briefly, BSA solutions were prepared by diluting a stock BSA solution $(1 \mathrm{mg} / \mathrm{ml})$ to $5 \mathrm{ml}$. BSA concentrations ranged from 0.05 to $1.00 \mathrm{mg} / \mathrm{ml}$. Based on these different dilutions, $0.2 \mathrm{ml}$ of protein solution was placed in different test tubes and $2 \mathrm{ml}$ of alkaline copper sulfate reagent (analytical reagent) was added. After the resulting solution was mixed properly, it was incubated at room temperature for $10 \mathrm{~min}$. Then, $0.2 \mathrm{ml}$ of reagent Folin-Ciocalteau solution was added to each tube and incubated for $30 \mathrm{~min}$. The colorimeter was calibrated with a blank, and the absorbance was measured at 660 $\mathrm{nm}$.

vii. Determination of Total Reducing Sugar Assay- 3,5Dinitrosalicylic acid (DNSA, IUPAC name 2-hydroxy3,5-dinitrobenzoic acid) is an aromatic compound that reacts with reducing sugars and other reducing molecules to form 3-amino-5-nitrosalicylic acid, which absorbs light strongly at $540 \mathrm{~nm}$ (In case of glucose).

\section{Procedure}

Take at least three $20 \mathrm{ml}$ test tubes (i.e. three replicates of each concentration should be tested) and took an amount of glucose stock solution in each test tube as per table given below Prepared a blank, in which case added $500 \mu$ l of DW instead of sample. Added DW as indicated in the table above (preheated to $65^{\circ} \mathrm{C}$ ). Incubated precisely at $65^{\circ} \mathrm{C}$ for $15 \mathrm{~min}$ in a water bath or incubator. Add $3 \mathrm{ml}$ of DNSA. Kept tubes (Glucose solution + DW + DNSA) in boiling water-bath for $15 \mathrm{~min}$. Cool at room temperature. Absorbance was measure at $540 \mathrm{~nm}$ in a UV Elico spectrophotometer BL-200 against a suitable blank.

\begin{tabular}{|c|c|c|c|c|}
\hline $\begin{array}{c}\text { Standard for DNSA methods. } \\
\text { Sr. No. }\end{array}$ & $\begin{array}{c}\text { Conc. of glucose } \\
(\boldsymbol{\mu} \mathbf{m o l})\end{array}$ & $\begin{array}{c}\text { Amount of working } \\
\text { solution }(\boldsymbol{\mu} \mathbf{l})\end{array}$ & $\begin{array}{c}\text { Volume of DW } \\
(\boldsymbol{\mu l})\end{array}$ & $\begin{array}{c}\text { Amount of DNSA } \\
(\mathbf{m l})\end{array}$ \\
\hline 1 & 1 & 100 & 1400 & 3 \\
\hline 2 & 2 & 200 & 1300 & 3 \\
\hline 3 & 3 & 300 & 1200 & 3 \\
\hline 4 & 4 & 400 & 1100 & 3 \\
\hline 5 & 5 & 500 & 1000 & 3 \\
\hline 6 & - & - & 1500 & 3 \\
\hline
\end{tabular}

viii. Determination of Glucose, Fructose and Fructose Glucose ratio- Glucose percentage is determined iodimetrically in a weak alkaline medium and the value is subtracted from reducing sugar percentage to arrive at fructose percentage and fructose: glucose ratio.

Glucose $\%=$ Normality of sodium thiosulphate solution $\times$ $(\mathrm{B}-\mathrm{S}) \times 0.009005 /(0.1 \mathrm{~N} \times$ weight of sample $) \times 100$

Fructose $\%=$ Reducing sugars $\%$ - glucose $\%$ Fructose Glucose ratio = Fructose $\% /$ Glucose $\%$

ix. Determination of Sucrose content: The sucrose content of the honey samples was determined according to the procedure of Lane and Eynon method (1923) ${ }^{[20]}$.

$2.6 \mathrm{~g}$ of honey were weighed and then transferred to a $500 \mathrm{ml}$ volumetric flask. Five milliliters of standardized Fehling $\mathrm{A}$ and $\mathrm{B}$ solutions were transferred to a $250 \mathrm{ml}$
Erlenmeyer flask, with $7 \mathrm{ml}$ of water and $15 \mathrm{ml}$ of honey solution. The Erlenmeyer flask was heated and $1 \mathrm{ml}$ methylene blue $0.2 \%$ was added. Titration was carried out adding the diluted honey solution until the indicator was decolorized. Determining sucrose content was carried out by inversion, adding $10 \mathrm{ml}$ of diluted $\mathrm{HCl}, 50$ $\mathrm{ml}$ diluted honey solution and water to a $100 \mathrm{ml}$ volumetric flask, heating in water bath, then cooling and diluting to mark. Finally the Lane-Enyon method was applied and sucrose content was obtained by difference. Apparent sucrose $=$ (Invert sugar $/ 100 \mathrm{gm}$ honey after inversion $)-($ Sugar content before inversion $) \times 0.95$.

The results were expressed as gm apparent sucrose/100 gm honey.

x. Determination of Proline content: Proline was determined by Ninhydrin method and results were recorded at $520 \mathrm{~nm}$ using a spectrophotometer. Honey 
solution $(1 \mathrm{~g} / 20 \mathrm{ml})$ was taken in three reaction tubes separately. Formic acid $(0.25 \mathrm{ml})$ (Riedel chemical, $85 \%)$ and ninhydrin solution (Spectrochem, 99\%) (1ml of 3\% ethylene glycol monoethylether) (Ranbaxy) were added into it. The tubes were tightly capped, shacked well and placed in boiling water bath for 15 minutes and cooled for 5 minutes at room temperature. Caps were removed and $5 \mathrm{ml}$ of aqueous isopropyl alcohol (50\% aq.IPA) (Qualigens, 99\%) was added into each reaction tubes. The content of the tubes were mixed well and absorbance was determined at $520 \mathrm{~nm}$, using the spectrophotometer (Elico, Model no.-BL 200). Absorbance of all samples was noted within the 35 minutes of cooling. Calibration curve plotted with standard solution of proline against absorbance. Proline in honey was calculated from standard curve.

xi. Determination of Lipid content- Lipid content was determined by Bligh and Dyer (1959) method [21]. Homogenize the sample $20 \mathrm{~g}$ with $16 \mathrm{ml}$ distilled water, $40 \mathrm{ml}$ of chloroform and $80 \mathrm{ml}$ of methanol at the speed of $9500 \mathrm{rpm}$ for $1 \mathrm{~min}$ at 4 degree C. Add $40 \mathrm{ml}$ of chloroform and homogenize for 30seconds. Add $40 \mathrm{ml}$ of distilled water and homogenize again for 30seconds. After centrifugation of the homogenate at 2000rpm at 4degree $\mathrm{C}$ for $20 \mathrm{~min}$ transfer the supernatant in to a seperatory funnel and allow it to separate. Determine lipid content gravimetrically by measuring triplicate aliquots of the chloroform layer into tared containers, evaporate the solvent and weigh. Calculate the lipid content.

\section{Results and Discussion}

The results of different parameters of all the raw blended honey samples collected in three different locations of Kannad taluka were compared with the Codex Alimentarius and European Standards [12]. It was observed that studied physicochemical parameters are within the normal ranges (Table 1 and 2).

Honey samples harvested in three different locations of Kannad taluka were obtained and used for the study. All the samples were collected freshly in sterile containers and stored at room temperature until analyzed. Unnecessary materials such as wax sticks, dead bees and particles of combs were removed before analysis.

The mean $\mathrm{pH}$ values of blended honey samples obtained from three different locations of Kannad taluka were within the range of 3.8 to 5.3. The $\mathrm{pH}$ is an important parameter during extraction and the conservation of honey. It increases the quality, constancy and shelf life of honey ${ }^{[22]}$. This parameter is related to fermentation process due to storage ${ }^{[23,24]}$. It is the helpful index for possibility of microbial growth, because of the presence of various organic acids viz., pyruvic acid, maleic acid, citric acid and gluconic acid in balance equilibrium with lactones, esters and inorganic ions like sulphate, phosphate and chloride ${ }^{[25]}$. Honey samples with a $\mathrm{pH}$ above 5 to be of low quality ${ }^{[26]}$. The analysis of $\mathrm{pH}$ in the honey is considered as one of the quality factors used in the international honey trade ${ }^{[27]}$.

Sajid et al., (2020) comparatively studied the pH of fresh and branded honey from Pakistan in the range of 4.35 to 7.5 in fresh honey and 4.6 to 5.35 in branded honeys ${ }^{[28]}$. Goncalves et al., (2018) studied the $\mathrm{pH}$ of selected Portuguese commercial monofloral honey samples in the range of 3.43$4.18^{[29]}$. Kumar et al., (2018) studied the pH of 100 Indian honey samples ranges from 3.81-4.85 [30]. Boussaid et al.,
(2018) studied the $\mathrm{pH}$ of six Tunisian honey samples from various floral origins ranges from 3.67-4.11 ${ }^{[10]}$. Lullah-Deh $e t$ al., (2018) studied the $\mathrm{pH}$ of seven honey samples from Mambilla Plateau, Nigeria ranged from 3.22 to $5.00^{\text {[31] }}$. Silva et al., (2017) reported the $\mathrm{pH}$ value of Portuguese honey from Castelo Branco region in the range of 5.53 to $5.33^{[32]}$.

Ndife et al., (2014) studied the pH of Nigerian honey sourced from different floral locations ranges from 4.10 to 4.58 [33]. Sohaimy et al., (2015) reported the $\mathrm{pH}$ of Egyptian, Kashmiri, Yemeni and Saudi honeys in the range 4.11- $4.63^{[34]}$. Buba et al., (2013) studied the $\mathrm{pH}$ of honey samples from North-East Nigeria ranged from 3.5-4.9 ${ }^{[35]}$. Liberato et al., (2013) reported the $\mathrm{pH}$ value of 22 honey samples from Ceara state, Northeastern Brazil ranges from 3.01-4.21 [36].

The mean values of moisture content in blended honey samples obtained from three different locations of Kannad taluka were within the range of 15.96 to $18.23 \%$. The moisture content of honey is an important quality parameter and influenced by various aspects such as maturity period, climatic conditions, harvesting time and type of honey ${ }^{[37,38]}$. Higher water content could lead to the fermentation of honey during storage $[39,40]$. The water content depends upon the environmental factors during production such as weather and humidity inside the hive, but also on nectar conditions and treatment of honey during extraction and storage ${ }^{[41]}$.

Sajid et al., (2020) comparatively studied moisture content in fresh and branded honey from Pakistan in the range of 18 to $19.07 \%$ in fresh honey and 19.50 to $21.25 \%$ in branded honey ${ }^{[28]}$. Goncalves et al., (2018) reported the moisture content of selected Portuguese commercial monofloral honey samples ranges between 15.7-16.5\% ${ }^{[29]}$. Kumar et al., (2018) reported the moisture content of 100 Indian honey samples ranges between 18.37-22\% [30]. Boussaid et al., (2018) reported the moisture content of six Tunisian honey samples from various floral origins ranges between 17.27-19.80\% ${ }^{[10]}$. Lullah-Deh et al., (2018) studied the moisture content of seven honey samples from Mambilla Plateau, Nigeria ranges between 16.4 to $34.0 \%{ }^{[31]}$. Trstenjak et al., (2017) studied the moisture content of 200 Acacia honey samples obtained from different regions of Croatia varied from 16.78-17.01\% ${ }^{[42]}$. Silva et al., (2017) reported the moisture content of Portuguese honey from Castelo Branco region in the range of 5.53 to $24.20 \%{ }^{[32]}$. Kaur et al., (2016) studied the moisture content of honey samples using GIS technique in selected states of Northern India ranged from 18.0 to $24.50 \%$ [43]. Sohaimy et al., (2015) studied the moisture content of Egyptian, Kashmiri, Yemeni and Saudi honey ranges between 14.73-18.32\% [34]. Ndife et al., (2014) reported the moisture content of Nigerian honey sourced from different floral locations ranges from $15.69-18.41 \%{ }^{[33]}$. Liberato et al., (2013) reported the moisture content of 22 honey samples from ceara state, Northeastern Brazil ranges between 13.63 to $20.80 \%{ }^{[36]}$.

The mean values of electrical conductivity in blended honey samples obtained from three different locations of Kannad taluka were within the range of 0.07 to $0.116 \mathrm{mS} / \mathrm{cm}$. EC is one of the most considerable factors for determining the physical characteristics of honey ${ }^{[44]}$. It is the indication of ionizable acids and compounds in an aqueous solution and is a good criterion used for the identification of honey quality and purity ${ }^{[45]}$.

Large amount of literature reported the different values of electrical conductivity. ${ }^{[46]}$ Iftikhar et al., (2014) studied the electrical conductivity of local and imported brands of honey 
samples available in the Rawalpindi and Islamabad markets in Pakistan ranged from 0.08 to $0.80 \mathrm{mS} / \mathrm{cm}$.

Sajid et al., (2020) comparatively studied electrical conductivity of fresh and branded honeys from Pakistan in the range of 0.11 to $0.20 \mathrm{mS} / \mathrm{cm}$ in fresh honey and 0.17 to 0.23 $\mathrm{mS} / \mathrm{cm}$ in branded honeys ${ }^{[28]}$. Goncalves et al., (2018) determined the electrical conductivity of selected Portuguese commercial monofloral honey samples ranges from 0.21 $0.60 \mathrm{mS} / \mathrm{cm}^{[29]}$. Kumar et al., (2018) reported the electrical conductivity of 100 Indian honey samples in range 0.28 $1.00 \mathrm{mS} / \mathrm{cm}^{[30]}$. Boussaid et al., (2018) reported the electrical conductivity of six Tunisian honey samples from various floral origins ranges between $0.39-0.89 \mathrm{mS} / \mathrm{cm}^{[10]}$. LullahDeh et al., (2018) studied the electrical conductivity of seven honey samples from Mambilla Plateau, Nigeria in the range of 7.6 to $12.4 \mu \mathrm{S} / \mathrm{m}^{[31]}$. Silva et al., (2017) reported the electrical conductivity value of Portuguese honey from Castelo Branco region in the range of 130.2 to $667.4 \mu \mathrm{S} / \mathrm{cm}^{[32]}$. Trstenjak et al., (2017) determined the electrical conductivity of 200 Acacia honey samples obtained from different regions of Croatia ranges between $0.150 .18 \mathrm{mS} / \mathrm{cm}^{[42]}$. Sohaimy et al., (2015) studied the electrical conductivity of Egyptian, Kashmiri, Yemeni and Saudi honey ranges between 0.53$4.18 \mathrm{mS} / \mathrm{cm}^{[34]}$. Buba et al., (2013) reported the electrical conductivity of honey samples from North-East Nigeria ranged from $0.05-0.41 \mathrm{mS} / \mathrm{cm}^{[35]}$.

The mean values of reducing sugar in blended honey samples obtained from three different locations of Kannad taluka were within the range of 59.93 to $65.74 \%$. Honey is a mixture of chiefly two reducing sugars namely glucose and fructose, giving it similar properties to invert syrup. This gives it the ability to remain liquid for long periods of time ${ }^{[47]}$. Sugars are the main constituents of honey comprising about $95 \%$ of honeys dry weight ${ }^{[48]}$. Reducing and non-reducing sugars together account for $85-95 \%$ of honey's carbohydrate and their amount depends on the source of nectar ${ }^{[49]}$.

Goncalves et al., (2018) determined the concentration of reducing sugars in selected Portuguese commercial monofloral honey samples ranges between $62.4-71.4 \mathrm{~g} / 100 \mathrm{~g}$ ${ }^{[29]}$. Kumar et al., (2018) determined the concentration of total reducing sugars in 100 Indian honey samples ranges between 64.91-71.39\% [30]. Aljohar et al., (2018) reported the concentration of total reducing sugars in honey samples available in the Saudi market ranges from 39.60-79.13\% [50]. Trstenjak et al., (2017) determined the concentration of total reducing sugars of 200 Acacia honey samples obtained from different regions of Croatia ranges between 68.46$70.62 \mathrm{~g} / 100 \mathrm{~g}{ }^{[42]}$. Kaur et al., (2016) studied the total reducing sugars of honey samples using GIS technique in selected states of Northern India ranged from 65.58 to $78.51 \%{ }^{[43]}$. Sohaimy et al., (2015) reported the concentration of total reducing sugars in Egyptian, Kashmiri, Yemeni and Saudi honeys ranges between $15.11-72.36 \%{ }^{\text {[34] }}$. Iftikhar et al., (2014) studied the total sugar content of local and imported brands of honey samples available in the Rawalpindi and Islamabad markets Pakistan ranged from 75.0 to $83.0 \%{ }^{[46]}$. Alemu et al., (2013) determined the reducing sugar of honey produced in Sekota district of Northern Ethiopia ranges between 63.4 to $71.7 \%{ }^{[47]}$.

The mean concentration of glucose in blended honey samples obtained from three different locations of Kannad taluka were within the range of 22.28 to $24.76 \%$. Kumar et al., (2018) determined the concentration of glucose in 100 Indian honey samples ranges between 26.13-46.94\% [30]. Boussaid et al.,
(2018) reported the of glucose concentration in six Tunisian honey samples from various floral origins ranges between 31.07-36.58\% [10]. Aljohar et al., (2018) reported the concentration of glucose in honey samples available in the Saudi market ranges from $16.26-42.84 \%{ }^{[50]}$. Sohaimy et al., (2015) reported the concentration of glucose in Egyptian, Kashmiri, Yemeni and Saudi honeys ranges between 10.63$26.54 \%{ }^{[34]}$. Buba et al., (2013) studied the glucose content of honey samples from North- East Nigeria ranges from 27.25 to $39.56 \%{ }^{[35]}$.

The mean concentration of fructose in blended honey samples obtained from three different locations of Kannad taluka were within the range of 35.17 to $43.46 \%$. Kumar et al., (2018) determined the concentration of fructose in 100 Indian honey samples ranges between 39.46-21.82\% [30]. Boussaid et al., (2018) reported the concentration of fructose in six Tunisian honey samples from various floral origins ranges between 35.78-37.84\% ${ }^{[10]}$. Aljohar et al., (2018) reported the fructose concentration in honey samples available in the Saudi market ranges from $2.63-39.14 \%{ }^{[50]}$. Sohaimy et al., (2015) reported the fructose concentration in Egyptian, Kashmiri, Yemeni and Saudi honeys ranges between $4.48-50.78 \%{ }^{[34]}$. Buba et al., (2013) studied the fructose content of honey samples from North- East Nigeria ranges from 37.68 to $40.31 \%{ }^{[35]}$.

The mean F/G ratios in blended honey samples obtained from three different locations of Kannad taluka were within the range of 1.42 to 1.95 . Boussaid et al., (2018) reported the fructose glucose ratio of six Tunisian honey samples from various floral origins ranges between 1.03-1.17 [10]. Aljohar et al., (2018) studied the fructose/glucose ratio of honey samples available in the Saudi market ranges between 0.13-1.63 ${ }^{[50]}$. Kaur et al., (2016) studied the F/G ratio of honey samples using GIS technique in selected states of Northern India ranged from0.92 to $1.18{ }^{[43]}$. Sohaimy et al., (2015) reported the fructose/glucose ratio of Egyptian, Kashmiri, Yemeni and Saudi honeys ranges between 0.42-2.35 [34]. Buba et al., (2013) studied the fructose/glucose ratio of honey samples from North- East Nigeria ranges from 1.00 to 1.45 Fructose/ glucose ratio indicates the ability of honey to crystallize ${ }^{[35]}$. White and Doner (1980) stated that even though honey has less glucose than fructose, it is the glucose that crystallizes when honey granulates because it is less soluble in water than fructose ${ }^{[51]}$. When the fructose/glucose ratio is high, honey remains liquid. Honey crystallization is slower when the fructose/glucose ratio is more than 1.3 and it is faster when the ratio is below $1.0^{[52]}$.

Hydroxymethylfurfural (HMF) content of honey is the important parameter to evaluate honey freshness and the heating or storage condition effects on honey quality. HMF or 5-hydroxymethyl-2- furfuraldehyde is an aldehyde and a furan compound which is formed after thermal decomposition of sugars and carbohydrates. HMF is found to be present in many food products like honey, fruit juice, syrup, jam etc. ${ }^{[53]}$. The amount of HMF in honey is one of the important indicators of honey quality. In fresh honey, HMF is present only in trace amounts and its concentration increases with storage and prolonged heating of honey ${ }^{[48]}$. The mean concentrations of HMF in blended honey samples obtained from three different locations of Kannad taluka were within the range of 9.28 to $20.90 \mathrm{mg} / \mathrm{kg}$. Goncalves et al., (2018) determined the HMF content of selected Portuguese commercial monofloral honey samples ranges between 7.4$28.4 \mathrm{mg} / \mathrm{kg}{ }^{[29]}$. Buba et al., (2013) reported the HMF content of honey samples from North-East Nigeria ranges between 
$5.99-17.22 \mathrm{mg} / \mathrm{kg}{ }^{[35]}$. Kumar et al., (2018) determined the HMF content of 100 Indian honey samples ranges between $3.65-23.16 \mathrm{mg} / \mathrm{kg}{ }^{[30]}$. Boussaid et al., (2018) reported the concentration of hydroxymethylfurfural of six Tunisian honey samples from various floral origins ranges between 12.07$27.43 \mathrm{mg} / \mathrm{kg}{ }^{[10]}$. Trstenjak et al., (2017) reported the HMF content of 200 Acacia honey samples obtained from different regions of Croatia ranges between $3.54-5.92 \mathrm{mg} / \mathrm{kg}{ }^{[42]}$. Kaur et al., (2016) studied the HMF content of honey samples using GIS technique in selected states of Northern India ranged from 0.24 to $58.00 \mathrm{mg} / \mathrm{kg}{ }^{[43]}$. Iftikhar et al., (2014) studied the HMF content of local and imported brands of honey samples available in the Rawalpindi and Islamabad markets of Pakistan ranged from 15 to $95 \mathrm{mg} / \mathrm{kg}{ }^{[46]}$.

The mean sucrose content in blended honey samples obtained from three different locations of Kannad taluka was within the range of 1.083 to $1.634 \mathrm{~g} / 100 \mathrm{~g}$. Goncalves et al., (2018) reported the sucrose content of selected Portuguese commercial monofloral honey samples ranges between 0.6$9.4 \mathrm{~g} / 100 \mathrm{~g}{ }^{[29]}$. Kumar et al., (2018) reported the sucrose content of 100 Indian honey samples ranges between 0.74$3.95 \%{ }^{[30]}$. Boussaid et al., (2018) determined the sucrose content of six Tunisian honey samples from various floral origins ranges between $0.20-4.60 \%{ }^{[10]}$. Aljohar et al., (2018) studied the sucrose content of honey samples available in the Saudi market ranges between $0.00-24.6 \%{ }^{[50]}$. Kaur et al., (2016) studied the sucrose content of honey samples using GIS technique in selected states of Northern India ranged from 0.41 to $3.10 \mathrm{~g} / 100 \mathrm{~g}{ }^{[43]}$. Sohaimy et al., (2015) determined the sucrose content of Egyptian, Kashmiri, Yemeni and Saudi honeys ranges between 1.34- 3.59g/100g [34]. Iftikhar et al., (2014) studied the sucrose content of local and imported brands of honey samples available in the Rawalpindi and Islamabad markets Pakistan ranged from 7.60 to $8.70 \%{ }^{[46]}$. Buba et al., (2013) studied the sucrose content of honey samples from North- East Nigeria ranges from0.53 to $3.29 \mathrm{gm} / 100 \mathrm{gm}^{[35]}$.

The mean concentrations of Proline in blended honey samples obtained from three different locations of Kannad taluka were within the range of 752.80 to $1039.97 \mathrm{mg} / \mathrm{kg}$. Sajid et al., (2020) comparatively studied proline content in fresh and branded honey from Pakistan in the range of 287.60 to $511.1 \mathrm{mg} / \mathrm{kg}$ in fresh honey and 103.66 to $329.66 \mathrm{mg} / \mathrm{kg}$ in branded honeys ${ }^{[28]}$. Goncalves et al., (2018) determined the concentration of proline in selected Portuguese commercial monofloral honey samples ranges between $412.3-566.6 \mathrm{mg} / \mathrm{kg}$ [29]. Boussaid et al., (2018) reported the proline content of six Tunisian honey samples from various floral origins ranges between 39.62-102.22mg/kg [10]. Cherian et al., (2011) studied the proline content of honey Produced by Apis cerana indica of Nagpur, Maharashtra (India) ranges between 131.1 to $423.4 \mathrm{mg} / \mathrm{kg}{ }^{[54]}$. Proline is one of the important amino acid found in honey. Proline was a criterion of honey ripeness and sugar adulteration ${ }^{[55]}$.

The mean concentration of protein in blended honey samples obtained from three different locations of Kannad taluka were within the range of 1.35 to $2.02 \mathrm{~g} / \mathrm{kg}$. Goncalves et al., (2018) reported the protein content of selected Portuguese commercial monofloral honey samples ranges between 0.16 $0.57 \mathrm{~g} / 100 \mathrm{~g}{ }^{[29]}$. Kumar et al., (2018) reported the protein content of 100 Indian honey samples ranges between 0.16 $0.70 \%{ }^{[30]}$. Boussaid et al., (2018) determined the protein content of six Tunisian honey samples from various floral origins ranges between $0.13-0.16 \%{ }^{[10]}$. Sohaimy et al., (2015) determined the protein content of Egyptian, Kashmiri, Yemeni and Saudi honeys ranges between $1.69-4.67 \mathrm{mg} / \mathrm{g}^{[34]}$. Ndife et al., (2014) reported the protein content of Nigerian honey sourced from different floral locations ranges from $0.90-1.15 \%{ }^{[33]}$. Liberato et al., (2013) reported the protein content of 22 honey samples from Ceara state, Northeastern Brazil ranges between 178 to $1121 \mu \mathrm{g} / \mathrm{gm}{ }^{[36]}$. Buba et al., (2013) studied the protein content of honey samples from North- East Nigeria ranges from 0.35 to $1.08 \mathrm{gm} / 100 \mathrm{gm}{ }^{[35]}$. Protein content in honey samples is reported to consist of mostly enzymes ${ }^{[56]}$. Cimpoiu et al., (2013) reported the total protein content of some Romanian honey ranges between 173 to $763 \mu \mathrm{g} / \mathrm{gm}^{[57]}$. Khalil et al., (2001) reported the protein content of different brands of unifloral honey available in the Northern region of Bangladesh in the range of 0.65 to $0.744 \%$ [58].

The mean values of lipid content in blended honey samples obtained from three different locations of Kannad taluka were within the range of 0.27 to $0.31 \mathrm{~g} / 100 \mathrm{~g}$. Ndife et al., (2014) reported the lipid content of Nigerian honey sourced from different floral locations ranges from $0.12-0.21 \%{ }^{[33]}$. Khalil et al., (2001) reported the lipid content of different brands of unifloral honey available in the Northern region of Bangladesh ranges between 0.134 to $0.146 \mathrm{gm} / 100$ gram ${ }^{[58]}$. Buba et al., (2013) reported the lipid content in honey samples from North- East Nigeria ranges from0.10$0.50 \mathrm{gm} / 100 \mathrm{gm}{ }^{[35]}$. Reports indicating that honey contains little or no fat are available in the literature ${ }^{[59,60]}$, but the presence of free fatty acids like palmitic, oleic and linolenic acids have been reported in white clover honey, thus indicating that honey consist of a very little amount of lipid and therefore not considered a good source of lipid ${ }^{[35]}$.

The mean concentrations of Vitamin $\mathrm{C}$ in blended honey samples obtained from three different locations of Kannad taluka were within the range of 626.33 to $949.55 \mathrm{mg} / \mathrm{kg}$. Rahman et al., (2014) found the values of vitamin $\mathrm{C}$ in the range of 100 to $1770 \mathrm{mg} / \mathrm{kg}$ in Pakistan honey ${ }^{[61]}$. Buba et al., (2013) determined the concentration of Vitamin $C$ in honey samples from North- East Nigeria ranges from 13.86 to $27.32 \mathrm{mg} / 100 \mathrm{gm}{ }^{[35]}$. Kesic et al., (2009) reported the concentration of vitamin $\mathrm{C}$ in the range of 37.22 to 378.30 $\mathrm{mg} / 100 \mathrm{gm}$ in honey from different locations of Bosnia Herzegovina ${ }^{[62]}$. Matei et al., (2004) determined the vitamin $\mathrm{C}$ content and some essential trace elements (NI, Mn, Fe, Cr) in bee products and the value of vitamin $\mathrm{C}$ ranges between 2.26 to $3.64 \mathrm{mg} / \mathrm{gm}^{[63]}$. Khalil et al., (2001) reported the vitamin $\mathrm{C}$ content of different brands of unifloral honey available in the Northern region of Bangladesh ranges between 4.2 to $6.25 \mathrm{mg} / 100 \mathrm{gm}^{[58]}$.

Honey consists of ascorbic acid because most flowers on which the bees forage contain this vitamin which serves as an antioxidant in addition to many other functions. Even, it has been shown that antioxidant activity of honey, which depends on its botanical origin, is related to its vitamin $\mathrm{C}$ contents; i.e., the content of vitamin $\mathrm{C}$ has a significant impact on the total antioxidant activity of honey ${ }^{[62]}$.

\section{Conclusion}

Overall results of physiochemical parameters indicate that the nutritional quality of honey was different from species to species and from location to location. It might be due their foraging sources. The honey obtained from agricultural and forest areas has highest nutritional quality than honey obtained from road side area. The average value of the 
physicochemical parameters found in the honey samples showed that honey harvested from the studied area is safe for human consumption according to Codex Alimentarius standards $[64,65,66]$ and for the commercialization of beekeeping practices to improve quality in the future this study utmost needed.

Table 1: Physical properties of blended raw honey harvested from three different locations of Kannad taluka of Aurangabad district.

\begin{tabular}{|c|c|c|c|}
\hline Collection Site & $\mathbf{p H}$ & Electrical Conductivity (mS/cm) & Moisture Content (\%) \\
\hline Agricultural Area & $4.2 \pm 0.15$ & $0.093 \pm 0.001$ & $17.33 \pm 0.94$ \\
\hline Forest Area & $3.8 \pm 0.12$ & $0.07 \pm 0.002$ & $15.96 \pm 0.92$ \\
\hline Road Side Area & $5.3 \pm 0.22$ & $0.116 \pm 0.005$ & $18.23 \pm 0.88$ \\
\hline Standards of Codex, 1993 and 2019. & $3.4-6.1$ & $0.8 \mathrm{mS} / \mathrm{cm}$ & $22 \%$ \\
\hline
\end{tabular}

Table 2: Biochemical properties of blended raw honey harvested from three different locations of Kannad taluka of Aurangabad district.

\begin{tabular}{|c|c|c|c|c|c|c|c|c|c|c|}
\hline $\begin{array}{l}\text { Site of Collection } \\
\text { \& Parameters }\end{array}$ & $\begin{array}{c}\text { Glucose } \\
\%\end{array}$ & $\begin{array}{c}\text { Fructose } \\
\%\end{array}$ & \begin{tabular}{|c|}
$\begin{array}{c}\text { Total reducing } \\
\text { sugar } \%\end{array}$ \\
\end{tabular} & $\begin{array}{c}\text { Sucrose } \\
\text { gm/100gm }\end{array}$ & \begin{tabular}{|c|}
$\mathbf{G} / \mathbf{F}$ \\
ratio
\end{tabular} & $\begin{array}{c}\text { HMF Content } \\
\mathrm{mg} / \mathrm{kg}\end{array}$ & $\begin{array}{c}\text { Proline } \\
\text { Conc.mg/kg }\end{array}$ & $\begin{array}{c}\text { Protein } \\
\text { gm/kg }\end{array}$ & $\begin{array}{c}\text { Lipid } \\
\text { gm/100gm }\end{array}$ & $\begin{array}{c}\text { Conc. of Vitamin } \\
\text { C mg/kg. }\end{array}$ \\
\hline Agricultural Area & $23.63 \pm 0.89$ & 39.09 & $62.72 \pm 2.14$ & $1.31 \pm 0.38$ & 1.65 & $14.52 \pm 0.72$ & $990 \pm 24.15$ & $2.02 \pm 0.2$ & $0.30 \pm 0.07$ & $828.43 \pm 17.88$ \\
\hline Forest Area & $22.28 \pm 0.89$ & 43.46 & $65.74 \pm 1.4$ & $1.63 \pm 0.22$ & 1.95 & $9.28 \pm 0.71$ & $1039.97 \pm 28.9$ & $2.01 \pm 0.2$ & $0.27 \pm 0.08$ & $949.55 \pm 31.44$ \\
\hline Road Side Area & $24.76 \pm 0.51$ & 35.17 & $59.93 \pm 1.73$ & $1.08 \pm 0.31$ & 1.42 & $20.90 \pm 0.8$ & $752.80 \pm 16.4$ & $1.35 \pm 0.1$ & $0.31 \pm 0.08$ & $626.33 \pm 13.75$ \\
\hline $\begin{array}{c}\text { Standards of Codex, } \\
1998 \text { and } 2019 .\end{array}$ & $23-32 \%$ & $\begin{array}{l}31.2- \\
42.4 \%\end{array}$ & $>60 \%$ & $\begin{array}{c}<5 \\
\mathrm{gm} / 100 \mathrm{gm}\end{array}$ & 0.95 & $<40 \mathrm{mg} / \mathrm{kg}$ & $>180 \mathrm{mg} / \mathrm{kg}$ & $\begin{array}{l}>0.1 \\
\mathrm{gm} / \mathrm{kg}\end{array}$ & $\begin{array}{c}0.10-0.50 \\
\mathrm{gm} / 100 \mathrm{gm}\end{array}$ & No fixed limits \\
\hline
\end{tabular}

\pm indicates standard deviation.

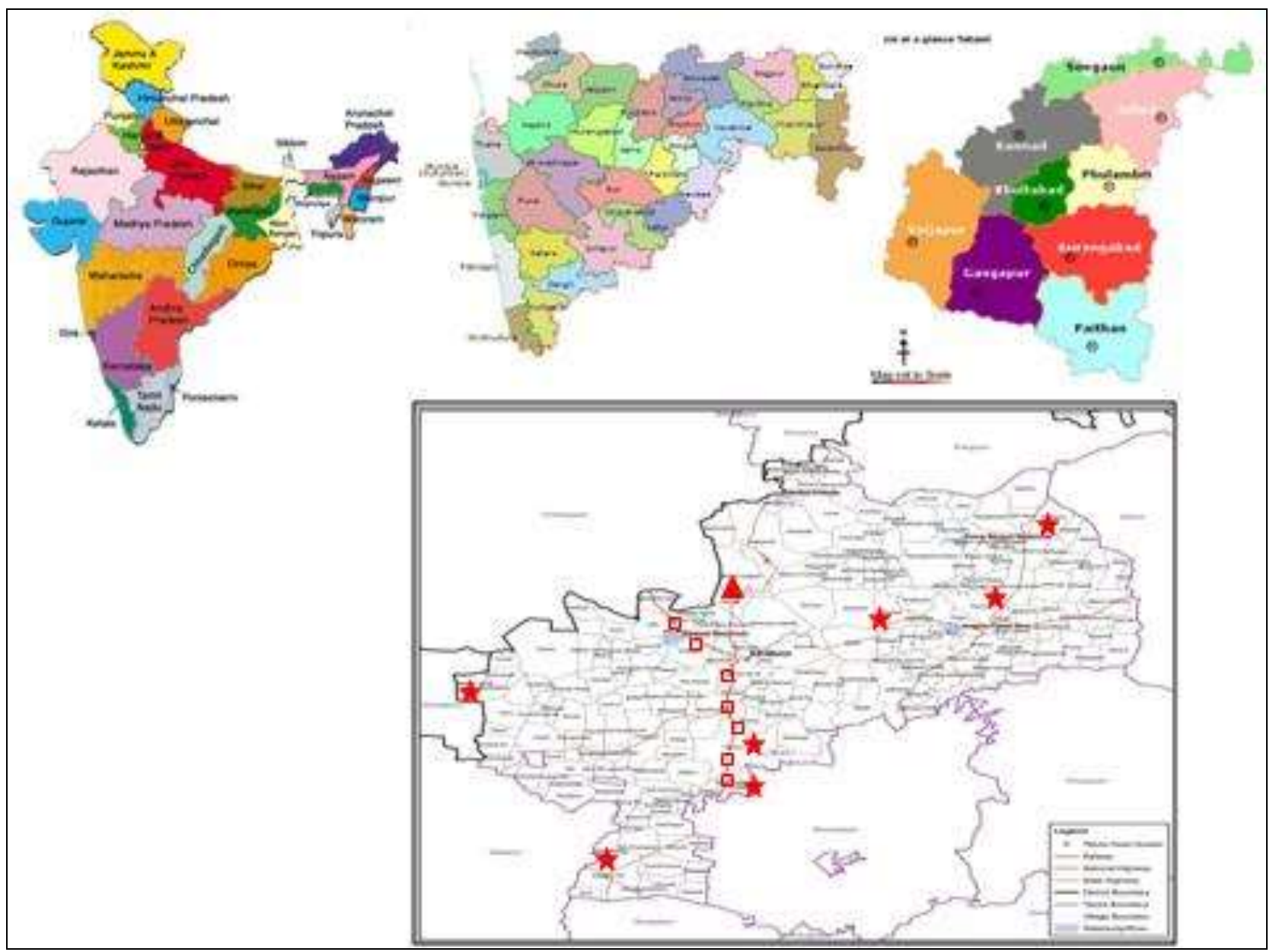

Fig 1: Location map

\section{Acknowledgements}

Authors are thankful to Head, Dept. of Zoology, Dr. Babasaheb Ambedkar Marathwada University, Aurangabad for providing the necessary laboratory facilities during the present work and university authorities for granting Golden Jubilee University Scholarship.

\section{References}

1. Codex Alimentarius. Draft revised standard for standard for honey (at step 10 of the Codex procedure). Alinorm. 2001;1(25):19-26.
2. Speer K, Montag A. Decomposition products of phenyl alanine as flavoring components in honey. Deutsche Lebensmittel-Rundschau 1987;83(4):103-107.

3. Qiu PY, Ding HB, Tang YK, Xu RJ. Determination of chemical composition of commercial honey by nearinfrared spectroscopy. Journal of Agricultural and Food Chemistry 1999;47(7):2760-5.

4. Sanz ML, Sanz J, Martınez-Castro I. Presence of some cyclitols in honey. Food Chemistry 2004;84(1):133-5.

5. Sato T, Miyata G. The nutraceutical benefit, part iii: honey. Nutrition (Burbank, Los Angeles County, Calif.). 
2000;16(6):468-9

6. Gheldof N, Engeseth NJ. Antioxidant capacity of honeys from various floral sources based on the determination of oxygen radical absorbance capacity and inhibition of in vitro lipoprotein oxidation in human serum samples. Journal of Agricultural and Food Chemistry 2002;50(10):3050-5.

7. Kahraman T, Buyukunal SK, Vural A, Altunatmaz SS. Physico-chemical properties in honey from different regions of Turkey. Food Chemistry 2010;123(1):41-4.

8. Seemann P, Neira M. Tecnología de la producciónapícola. Valdivia: Universidad Austral de Chile; Facultad de Ciencias Agrarias Empaste 1988, 202.

9. Lazarević KB, Andrić F, Trifković J, Tešić Ž, Milojković-Opsenica D. Characterisation of Serbian unifloral honeys according to their physicochemical parameters. Food Chemistry 2012;132(4):2060-4

10. Boussaid A, Chouaibi M, Rezig L, Hellal R, Donsì F, Ferrari G et al. Physicochemical and bioactive properties of six honey samples from various floral origins from Tunisia. Arabian Journal of Chemistry 2018;11(2):26574.

11. Sakač MB, Jovanov PT, Marić AZ, Pezo LL, Kevrešan ŽS, Novaković AR et al. Physicochemical properties and mineral content of honey samples from Vojvodina (Republic of Serbia). Food Chemistry 2019;276:15-21.

12. European Commission Council Directive. 2001/112/EC of 20 December 2001 relating to fruit juices and certain similar products intended for human consumption. Official Journal of European Communities 2002;L10:5866.

13. Bogdanov S, Lüllmann C, Martin P, von der Ohe W, Russmann $\mathrm{H}$, Vorwohl $\mathrm{G}$ et al. Honey quality and international regulatory standards: review by the International Honey Commission. Bee World 1999;80(2):61-9.

14. Joshi SR, Pechhacker H, von der Ohe W. Physico chemical properties of Apis dorsata honeys from Chitwan district, Nepal. In Proceedings of the Seventh International Conference on Tropical Bees: Management and Diversity 2000, 71-76.

15. Patel BK, Bhattacharya S. Coating with honey: A study with model solids. Journal of Food Process Engineering 2002;25(3):225-32.

16. Naik VN. Flora of Marathwada. Vol. I. II, Amrut Prakashan, Aurangabad 1998, 237-319.

17. AOAC. Official methods of analysis of AOAC international $15^{\text {th }}$ ed. Association of Official Analytical Chemist. Virginia. USA, Arlington 2000.

18. White Jr JW. Spectrophotometric method for hydroxymethylfurfural in honey. Journal of the Association of Official Analytical Chemists 1979;62(3):509-14.

19. Lowry OH, Rosebrough NJ, Farr AL, Randall RJ. Protein measurement with the Folin phenol reagent. Journal of Biological Chemistry 1951;193:265-275.

20. Lane J, Eynon L. Determination of reducing sugar by means of Fehling's solution with methylene blue as internal indicator. Journal of the Society of Chemical Industry 1923;42:32-36.

21. Bligh EG, Dyer WJ. A rapid method of total lipid extraction and purification. Canadian Journal of Biochemistry and Physiology 1959;37(8):911-7.

22. Terrab A, Díez MJ, Heredia FJ. Characterisation of
Moroccan unifloral honeys by their physicochemical characteristics. Food Chemistry 2002;79(3):373-9.

23. Gomes S, Dias LG, Moreira LL, Rodrigues P, Estevinho L. Physicochemical, microbiological and antimicrobial properties of commercial honeys from Portugal. Food and Chemical Toxicology 2010;48(2):544-8.

24. Silva TM, dos Santos FP, Evangelista-Rodrigues A, da Silva EM, da Silva GS, de Novais JS et al. Phenolic compounds, melissopalynological, physicochemical analysis and antioxidant activity of jandaíra (Melipona subnitida) honey. Journal of Food Composition and Analysis 2013;29(1):10-8.

25. Silva LR, Videira R, Monteiro AP, Valentão P, Andrade PB. Honey from Luso region (Portugal): Physicochemical characteristics and mineral contents. Microchemical Journal 2009;93(1):73-7.

26. Chefrour A, Draiaia R, Tahar A, Ait Kaki Y, Bennadja S, Battesti MJ. Physicochemical characteristics and pollen spectrum of some north-east Algerian honeys. AJFAND Online 2009;9(9):1276-1293.

27. Muli E, Munguti A, Raina SK. Quality of honey harvested and processed using traditional methods in rural areas of Kenya. Acta Veterinaria Brno 2007;76(2):315-20.

28. Sajid M, Yamin M, Asad F, Yaqub S, Ahmad S, Mubarik MA et al. Comparative study of physio-chemical analysis of fresh and branded honeys from Pakistan. Saudi Journal of Biological Sciences 2020;27(1):173-6.

29. Gonçalves J, Ribeiro I, Marçalo J, Rijo P, Faustino C, Pinheiro L. Physicochemical, antioxidant and antimicrobial properties of selected Portuguese commercial monofloral honeys. Journal of Food and Nutrition Research 2018;6(10):645-54.

30. Kumar A, Gill JP, Bedi JS, Manav M, Ansari MJ, Walia GS. Sensorial and physicochemical analysis of Indian honeys for assessment of quality and floral origins. Food Research International 2018;108:571-83.

31. Lullah-Deh JA, Khan ME, Eneji IS. Physicochemical characteristics of honey samples from Mambilla Plateau, Nigeria. Journal of Biomaterials 2018;2(1):7-11.

32. Silva LR, Sousa A, Taveira M. Characterization of Portuguese honey from Castelo Branco region according to their pollen spectrum, physicochemical characteristics and mineral contents. Journal of Food Science and Technology 2017;54(8):2551-61.

33. Ndife J, Abioye L, Dandago M. Quality assessment of Nigerian honey sourced from different floral locations. Nigerian Food Journal 2014;32(2):48-55.

34. El Sohaimy SA, Masry SH, Shehata MG. Physicochemical characteristics of honey from different origins. Annals of Agricultural Sciences 2015;60(2):27987.

35. Buba F, Gidado A, Shugaba A. Analysis of biochemical composition of honey samples from North-East Nigeria. Biochemistry and Analytical Biochemistry 2013;2(3):139.

36. Liberato MD, Morais SM, Magalhães CE, Magalhães IL, Cavalcanti DB, Silva MM. Physicochemical properties and mineral and protein content of honey samples from Ceará State, Northeastern Brazil. Food Science and Technology 2013;33(1):38-46.

37. Nanda V, Sarkar BC, Sharma HK, Bawa AS. Physicochemical properties and estimation of mineral content in honey produced from different plants in Northern India. 
Journal of Food Composition and Analysis 2003;16(5):613-9.

38. Nayik GA, Nanda V. Physico-chemical, enzymatic, mineral and colour characterization of three different varieties of honeys from Kashmir valley of India with a multivariate approach. Polish Journal of Food and Nutrition Sciences 2015;65(2):101-8.

39. Al ML, Daniel D, Moise A, Bobis O, Laslo L, Bogdanov S. Physico-chemical and bioactive properties of different floral origin honeys from Romania. Food Chemistry. 2009; 112(4):863-7.

40. Saxena S, Gautam S, Sharma A. Physical, biochemical and antioxidant properties of some Indian honeys. Food Chemistry 2010;118(2):391-7.

41. Gairola A, Tiwari P, Tiwari JK. Physico-chemical properties of Apis cerana-indica F. honey from Uttarkashi district of Uttarakhand, India. Journal of Global Biosciences 2013;2(1):20-5.

42. Uršulin-Trstenjak N, Puntarić D, Levanić D, Gvozdić V, Pavlek Ž, Puntarić A et al. Pollen, Physicochemical, and Mineral Analysis of Croatian Acacia Honey Samples: Applicability for Identification of Botanical and Geographical Origin. Journal of Food Quality. Article ID 8538693, 2017;11.

43. Kaur P, Mishra AA, Lal D. Honey characterization based on physicochemical parameters using GIS techniques: A case study in selected states of Northern India. Journal of Food Processing and Technology 2016;7(626):2.

44. Serrano S, Villarejo M, Espejo R, Jodral M. Chemical and physical parameters of Andalusian honey: classification of Citrus and Eucalyptus honeys by discriminant analysis. Food Chemistry 2004;87(4):61925.

45. Acquarone C, Buera P, Elizalde B. Pattern of $\mathrm{pH}$ and electrical conductivity upon honey dilution as a complementary tool for discriminating geographical origin of honeys. Food Chemistry 2007;101(2):695-703.

46. Iftikhar F, Mahmood R, Islam N, Sarwar G, Masood MA, Shafiq H. Physicochemical analysis of honey samples collected from local markets of Rawalpindi and Islamabad, Pakistan. American Journal of Biochemistry 2014;4(2):35-40.

47. Alemu T, Seifu E, Bezabih A. Physicochemical properties of honey produced in Sekota district, northern Ethiopia. International Food Research Journal 2013;20(6):3061.

48. Bogdanov S. The honey book, Bee Product Science, Switzerland, [Online] 2011. http://www.bee-hexagon.net

49. Cavian M. Evolution of glucose and fructose in one year: influence of induced granulation. Food Chemistry 2002;78:157-161.

50. Aljohar HI, Maher HM, Albaqami J, Al-Mehaizie M, Orfali R, Orfali R et al. Physical and chemical screening of honey samples available in the Saudi market: An important aspect in the authentication process and quality assessment. Saudi Pharmaceutical Journal 2018;26(7):932-42.

51. White JW, Doner LW. Honey composition and properties. Agriculture handbook 1980;335:82-91.

52. Amir Y, Yesli A, Bengana M, Sadoudi R, Amrouche T. Physico-chemical and microbiological assessment of honey from Algeria. Electronic Journal of Environmental, Agricultural and Food Chemistry 2010;1:9(9).
53. Makawi SZ, Taha MI, Zakaria BA, Siddig B, Mahmod $\mathrm{H}$, Elhussein AR et al. Identification and quantification of 5-hydroxymethyl furfural HMF in some sugarcontaining food products by HPLC. Pakistan Journal of Nutrition. 2009;8(9):1391-6.

54. Cherian KJ, Bhowal M, Godghate SD. Pollen and physicochemical analysis of honey produced by Apis cerana indica of Nagpur, Maharashtra (India). Journal of Environmental Research and Deveolopment 2011.

55. Von der Ohe W, Dustmann JH, von der Ohe K. Proline as a criterion of honey maturity. Deutsche LebensmittelRundschau 1991;87:383-6.

56. White JW. Physical characteristics of honey. In: Crane, E. (ed.), Honey, a Comprehensive Survey, Hienemann, London, UK. 197, 207-239.

57. Cimpoiu C, Hosu A, Miclaus V, Puscas A. Determination of the floral origin of some Romanian honeys on the basis of physical and biochemical properties. Spectrochimica Acta Part A: Molecular and Biomolecular Spectroscopy 2013;100:149-54.

58. Khalil MI, Motallib MA, Anisuzzaman AS, Sathi ZS, Hye MA, Shahjahan M. Biochemical analysis of different brands of unifloral honey available at the northern region of Bangladesh. Sciences 2001;1(6):385-38.

59. Tan ST, Holland PT, Wilkins AL, Molan PC. Extractives from New Zealand honeys. 1. White clover, manuka and kanuka unifloral honeys. Journal of Agricultural and Food Chemistry 1988;36(3):453-60.

60. Singh N, Bath PK. Quality evaluation of different types of Indian honey. Food Chemistry 1997;58(1, 2):129-33.

61. Khaliqur R, Muhammadzai MI, Hussain A, Halimur Rahman AJ. Contaminants Analysis of Different Branded and Unbranded Honey of khyber pukhtounkhwa Pakistan. Life Science Journal 2014;11(3):227-31.

62. Kesić A, Mazalović M, Crnkić A, Ćatović B, Hadžidedic Š, Dragošević G. The influence of L-ascorbic acid content on total antioxidant activity of bee-honey. European Journal of Scientific Research, Euro Journals Publishing 2009, 95-101.

63. Matei N, Birghila S, Dobrinas S, Capota $P$. Determination of $\mathrm{C}$ vitamin and some essential trace. Acta Chimica Slovenica 2004;51:169-75.

64. Codex Alimentarius. Standard for honey. Ref Nr. CL. 1993; 14-SH FAO and WHO, Rome, 27.

65. Codex Alimentarius. Draft revised for honey at step 6 of the Codex Procedure. CX 5/10.2, CL 1998/ 12-S.

66. Codex Alimentarius. Draft revised standard for standard for honey at step 10 of the Codex procedure. CSX 12. Adopted in 1981, Revised in 1987, 2001. Amended in 2019, 1-7. 